\title{
PEMANFAATAN TEKNOLOGI SMS GATEWAY SISTEM ADMINISTRASI KENDARAAN BERMOTOR PADA PT. RIAU ARGO PERKASA
}

\author{
Darmanta Sukrianto ${ }^{1),}$ Kartika Saputri ${ }^{2)}$ \\ Prodi Manajemen Informatika, AMIK Mahaputra Riau \\ Email:리arman1407@gmail.com, ${ }^{2}$ saputrikartika6@gmail.com
}

\begin{abstract}
Vehicle Administration is a piece of evidence attached to a two-wheeled or wheeled vehicle four containing the registration number and ownership identification of a motorized vehicle consisting of the Vehicle License Plate, STNK and BPKB. PT. Riau Argo Perkasa is engaged in the sale of two-wheeled motorized vehicles, every consumer who has purchased a vehicle will be provided with Vehicle Administration equipment. The system that is currently running, the delivery of information about taking Vehicle Administration is only notified when the consumer makes a purchase, it will make it difficult for the consumer to know that the fixed information of the Vehicle Administration has come out and can be retrieved. The purpose of this study is to design a system to provide information to consumers about vehicle administration snacks by utilizing the SMS gateway information system technology using the PHP programming language as a data processor and MySQL as an electronic storage medium. The application design method used is the waterfall method. Based on the results of this study, technology with SMS Gateway can provide easy and realtime information to consumers for taking Vehicle Administration that consumers have purchased, so they don't have to ask back and forth to the company.
\end{abstract}

Keywords : Administration, Information Systems, SMS Gateway

\begin{abstract}
Abstrak
Administrasi Kendaraan adalah suatu alat bukti yang melekat pada suatu kendaraan roda dua maumpun roda empat yang berisi nomor registrasi dan identifikasi kepemilikan suatu kendaraan bermotor yang terdiri dari Plat Kendaraan, STNK dan BPKB. PT. Riau Argo Perkasa bergerak dibidang penjualan kendaraan bermotor roda dua, setiap konsumen yang telah melakukan pembelian kendaraan akan diberikan kelengkapan Administrasi Kendaraan. Sistem yang berjalan sekarang penyampaian informasi tentang pengambilan Adminstrasi Kendaraan hanya diberitahukan pada saat konsumen melakukan pembelian, maka akan menyulitkan konsumen dalam mengetahui informasi tetapnya Administrasi Kendaraan tersebut sudah keluar dan dapat diambil. Tujuan penelitian ini adalah merancang sistem untuk memberikan informasi ke pada konsumen mengenai pengamilan Administrasi Kendaraan dengan memanfaatkan teknologi sistem informasi SMS Gateway menggunakan bahasa pemograman PHP sebagai pengolah data dan MySQL sebagai media penyimpanan secara elektronik. Metode perancangan aplikasi yang digunakan yaitu metode waterfall. Berdasarkan hasil penelitian ini teknologi dengan SMS Gateway dapat memberikan informasi yang mudah dan realtime kepada konsumen untuk pengambilan Administrasi Kendaraan yang konsumen telah beli, sehingga tidak harus bolak balik menanyakan kepada pihak perusahaan.
\end{abstract}

Kata Kunci : Administrasi, Sistem Informasi, SMS Gateway 


\section{PENDAHULUAN}

Administrasi adalah suatu kegiatan yang meliputi catat-mencatat, suratmenyurat, pembukuan ringan, ketikmengetik, agenda dan sebagainya yang bersifat teknis ketatausahaan (Khaerunnisa \& Nofiyati, 2020). Administrasi memegang peranan yang sangat penting terhadap tercapainya kelancaran usaha kegiatan, ataupun kegiatan yang dilakukan oleh perusahaan atau instansi.

Sistem adalah sekelompok komponen dan elemen yang digabungkan menjadi satu untuk mencapai tujuan tertentu. Sistem berasal dari bahasa Latin (systēma) dan bahasa Yunani (sustēma) adalah suatu kesatuan yang terdiri komponen atau elemen yangdihubungkan bersama untuk memudahkan aliran informasi, materi atau energi untuk mencapai suatu tujuan (Simangunsong, 2018).

Menurut Nugraha, A., $\mathrm{R}$ \& Lestrian, D Informasi adalah data yang diolah menjadi bentuk yang berguna dan berarti bagi yang menerimanya, informasi disebut juga data yang diproses atau data yang memiliki arti (Ramdhani Nugraha \& Lestrian, 2019). Informasi merupakan sebuah istilah yang tepat dalam pemakaian umum, informasi dapat mengenai data mentah, data tersusun, kapasitas sebuah saluran komunikasi, dan lain sebagainya. Dari beberapa definisi di atas dapat ditarik kesimpulan bahwa informasi adalah sebagai data yang sudah diolah, dibentuk, atau dimanipulasi sesuai dengan keperluan tertentu.

Sistem informasi merupakan suatu perkumpulan data yang terorganisasi beserta tatacara penggunaannya yang mencakup lebih jauh dari pada sekedar penyajian. Istilah tersebut menyiratkan suatu maksud yang ingin dicapai dengan jalan memilih dan mengatur data serta menyusun tatacara penggunaannya.Keberhasilan suatu sistem informasi yang diukur berdasarkan maksud pembuatannya tergantung pada tiga faktor utama, yaitu: keserasian dan mutu data, pengorganisasian data, dan tatacara penggunaanya(Enjelita \& Oktarina, 2019).

PT. Riau Argo Perkasa adalah salah satu perusahaan di bidang penjualan kendaraan bermotor yang berada di kota Pekanbaru. Setiap kendaraan bermotor yang di beli konsumen nantinya akan diberikan Plat Kendaraan, STNK dan $B P K B$, kendaraan tersebut. Pihak Sales Counter akan menjelaskan kapan Administrasi kendaraan tersebut akan keluar dan diberikan, tetapi tepatnya belum pasti karena pengurusan surat-surat tersebut terbilang selesai dalam waktu lama dan ada juga dalam waktu singkat,

Sistem informasi yang berjalan sekarang penyampaian informasi hanya dilakukan pada saat konsumen melakukan pembelian, kapan perkiraan administrasi kendaraan bisa diambil masih dalam bentuk estimasi waktu. Sering konsumen harus bolak balik ke perusahaan untuk menanyakan apakah adminstrasi kendaraan mereka sudah siap, apalagi letak tempat tinggal konsumen yang beragam bahkan ada yang sampai dari luar kota.

Teknologi informasi dapat didefinisikan sebagai perpaduan antara teknologi komputer dan telekomunikasi dengan teknologi lainnya seperti perangkat keras, perangkat lunak, database, teknologi jaringan, dan peralatan teknologi lainnya. Selanjutnya teknologi informasi digunakan untuk menyediakan informasi bagi para pemakai dalam rangka pengambilan keputusan (Himmah \& Azisi, 2019).

Melihat permasalahan tersebut sistem yang berjalan sekarang sangat tidak efektif lagi, konsumen tidak bisa mendapatkan informasi yang secara langsung dan menyita waktu serta biaya konsumen yang harus bolak balik menanyakan kepastian untuk mendapatkan adminstrasi kendaraan mereka yang dibeli. Jika sistem ini terus dipertahankan pelayanan terhadap konsumen yang akan membeli kendaraan di perusahaan tersebut 
nanti akan tertinggal dengan perusahaan yang sejenis yang telah memanfaatkan teknologi informasi.

Menurut Maimunah dkk SMS Gateway dapat didefinisikan sebagai suatu sistem atau mekanisme yang memfasilitasi transisi SMS dengan mengubah pesan dari beberapa jenis media komunikasi untuk lalu lintas jaringan seluler" sistem SMS gateway mirip dengan konsep email biasa atau SMS dalam hal sistem menerima pesan dari klien pengirim dan kemudian menyampaikan ke klien penerima (Maimunah et al., 2017).

SMS Gateway memungkinkan untuk sebuah pesan dapat di kirimkan dari sebuah aplikasi melalui jaringan operator telekomunikasi untuk di kirimkan ke nomor nomor tujuan. Dengan menggunakan aplikasi SMS Gateway ,sumber data bisa didapatkan langsung dari basis data untuk selanjutnya di olah menjadi informasi dan dikirimkan secara sistemik / tanpa manual kepada banyak nomor dalam satu waktu.

PHP ( Hypertext Preprocessor) adalah script yang ditanam di sisi server. PHP juga dilengkapi dengan berbagai macam pendukung lain seperti support langsung ke berbagai macam database yang popular (Fandhilah et al., 2017).

MySQL merupakan database server yang bersifat multiuser dan multithreaded. SQL adalah bahasa database standar yang memudahkan penyimpanan, pengubahan dan akses informasi. Pada MySQL dikenal istilah database dan tabel. Tabel adalah sebuah struktur data dua dimensi yang terdiri dari baris-baris record dan kolom (Nurmalasari et al., 2019).

Pengembangan aplikasi berbasis SMS Gateway menggunakan bahasa pemograman dan database sebagai media penyimpanan elektronik untuk pengolahan data menjadi solusi dalam pemecahan masalah karena sistem aplikasi ini memudakan pengolahan data konsumen dan dalam menyampaikan informasi dengan cepat. Dengan memanfaatkan teknologi informasi SMS Gateway konsumen sehingga tanpa harus datang kekantor hanya untuk menanyakan kapan adminstrasi Kendaraan tersebut keluar dan dapat diambil.

\section{METODOLOGI PENELITIAN}

Metodologi untuk pengembangan sistem merupakan proses standar yang digunakan pengembang untuk menghubungkan semua langkah yang diperlukan untuk menganalisa, merancang, mengimplementasikan, dan memelihara sistem informasi. Dalam penelitian ini metode penelitian yang digunakan adalah System Development Life Cycle (SDLC).

System Develompment Life Cycle (SDLC) atau disebut juga dengan Waterfall. SDLC merupakan metode yang digunakan untuk mengembangkan maupun merekayasa Sistem Informasi. Metode ini bersifat menyeluruh dan merupakan kumpulan langkah-langkah yang menjadi pedoman dalam mengembangkan Sistem Informasi dan berpengaruh langsung terhadap kualitas dari hasil akhir Sistem Informasi tersebut. Adapun yang menjadi langkah langkah yang menjadi pedoman dalam pengembangan Sistem Informasi dapat dilihat pada gambar 1 sebagai berikut :

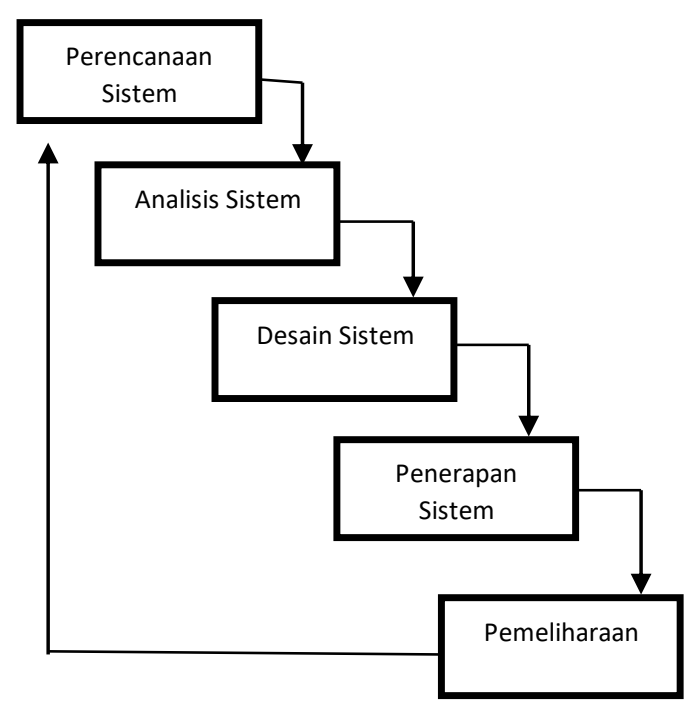

Gambar 1. SDLC 


\section{Perencanaan Sistem (System Planning)}

Pada tahap ini yaitu melakukan pengamatan secara langsung, wawancara tanya jawab untuk mendefinisikan masalah dan menentukan tujuan sistem. Selanjutnya mencari literature yang berkaitan dengan topik penelitian.

\section{Analisis Sistem}

Tahapan pada proses pengumpulan data baik data kuantitatif maupun kualitatif guna mendapatkan data-data kebutuhan sistem dari pemecahan identifikasi masalah yang timbul untuk di analisa dalam pembuatan aplikasi yang diinginkan dengan melihat bagaimana prosedure pada sistem pelayanan yang berjalan pada PT. RIAU ARGO PERKASA dan teknologi yang tepat yaitu menggunakan SMS Gateway.

\section{Desain Sistem}

Melakukan perancangan terhadap seluruh desain sistem mulai dari desain alur sistem menggunakan Unified Modeling Language (UML), rancangan database, rancangan desain tabel, desain input dan output.

4. Penerapan

Dalam tahap ini dilakukan dengan mengubah desain sistem ke bahasa pemograman PHP dan database MySQL sebagai media penyimpanan elektronik dan SMS Gateway teknologi pengiriman informasi.

5. Pemeliharaan

Pemeriksaan secara berkala/periodik, memperkaya atau mengembangkan sistem dengan penambahan fitur-fitur baru yang dapat meningkatkan kinerja sistem.

\section{HASIL DAN PEMBAHASAN}

3.1 Rancangan Sistem

3.2 UsecaseDiagram

Use case mendeskripikan sebuah interaksi antara satu atau lebih aktor dengan sistem informasi yang akan dibuat. Use case digunakan untuk mengetahui fungsi apasaja yang ada di dalam sebuah sistem dan siapa saja yang berhak menggunakan fungsi tersebut.

\subsubsection{Usecase Diagram Sistem Berjalan}

Berikut merupakan gambaran sistem pengambilan STNK yang sedang berjalan di PT. RIAU ARGO PERKASA pada gambar 2 sebagai berikut :

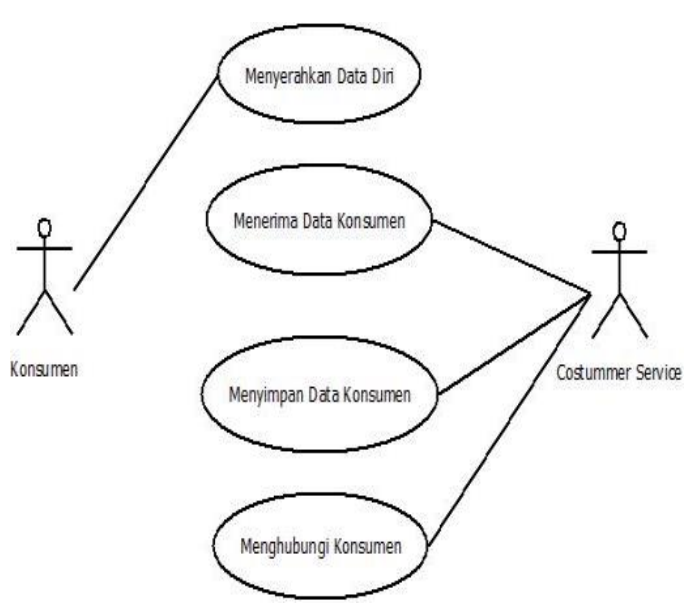

Gambar 2. Usecase Diagram Berjalan

\subsubsection{Usecase Diagram Sistem Usulan}

Berikut merupakan gambaran sistem adminstrasi usulan di PT. RIAU ARGO PERKASA pada gambar 3 sebagai berikut

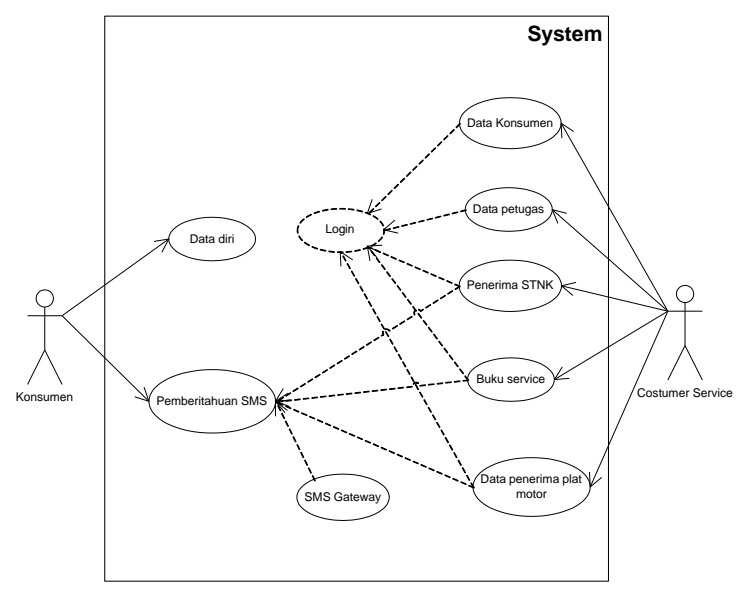

Gambar 3. Usecase Diagram usulan

\subsection{Class Diagram}

Diagram kelas atau class diagram menggambarkan struktur sistem dari segi pendefinisian kelas-kelas yang akan dibuat untuk membangun sistem, adapun gambar class diagram bisa dilihat pada Gambar 4 sebagai berikut : 


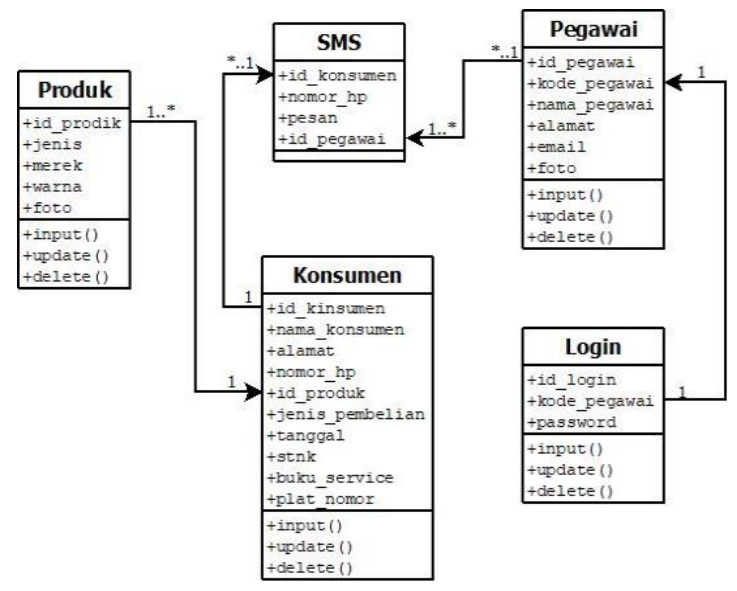

Gambar 4. Class Diagram

\subsection{Perancangan Antar Muka}

1. Halaman Konsumen

Ketika pertama kali memasuki sistem maka akan di tampilkan halaman pelanggan atau landing page. Halaman ini berfungsi untuk penampilkan data produk terbaru, halaman untuk konsumen menginput data dirinya dan kontak dealler honda. Dapat di lihat pada gambar 5, 6 dan 7 di bawah ini :
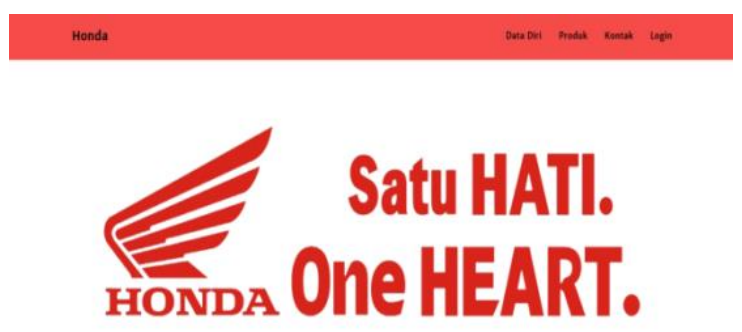

Gambar 5. Halaman Konsumen

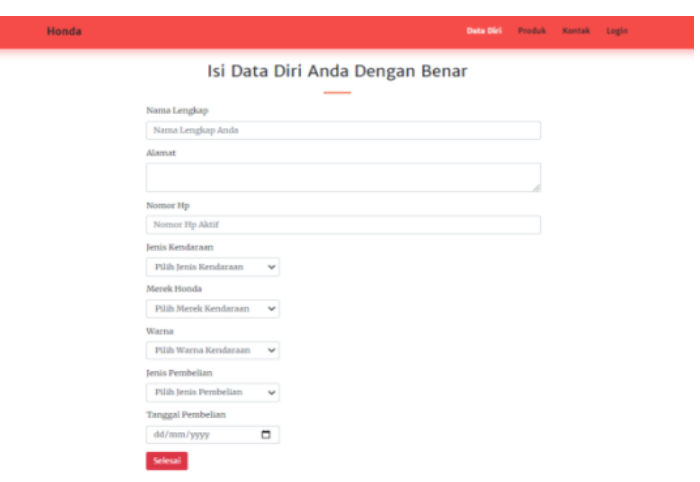

Gambar 6. Halaman Input Data Diri

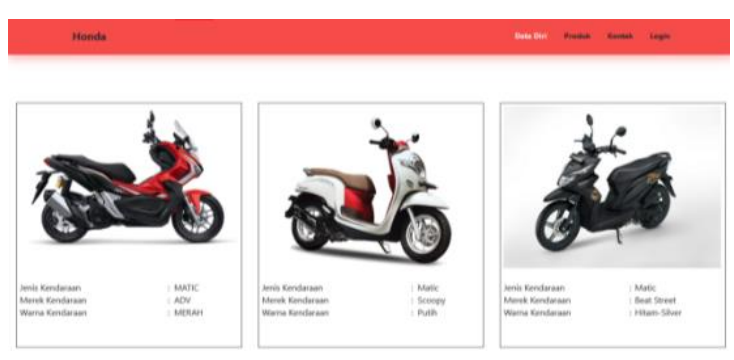

Gambar 7. Halaman Data produk

\section{Form Login}

Form login adalah halaman awal dimana pada halaman form login ini user yang terdaftar pada sistem akan mengisikan username dan password . Jika username atau password salah user tidak bisa masuk ke menu sistem selanjutnya. Form login pada gambar 8 sebagai berikut

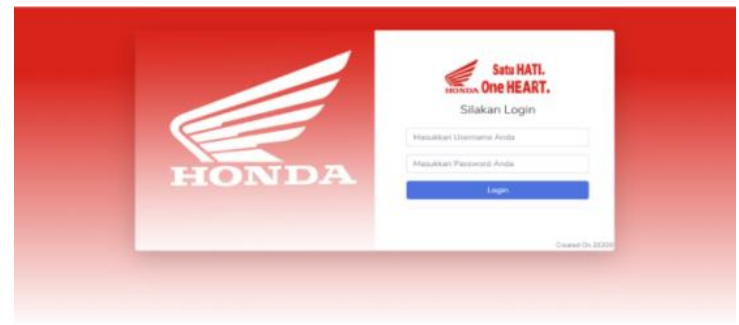

Gambar 8. Form login

3. Halaman Dashboard

Setelah login maka akan di tampilkan halaman Dashboard. Halaman dashboard sendiri merupakan halaman yang dijumpai setelah melakukan login. Halaman dashboard dapat dilihat pada gambar 9 berikut ini :

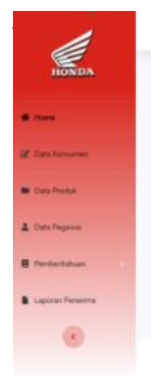

\section{Satu HATI. HONda One MEART.}

Gambar 9. Halaman Dashboard 
4. Halaman data konsumen dan form input konsumen

Halaman data konsumen merupakan halaman yang berfungsi untuk menampilkan data konsumen yang dimana terdapat tombil untuk menambahkan data konsumen pada halaman yang sama. Halaman data konsumen dapat di lihat pada gambar berikut ini :

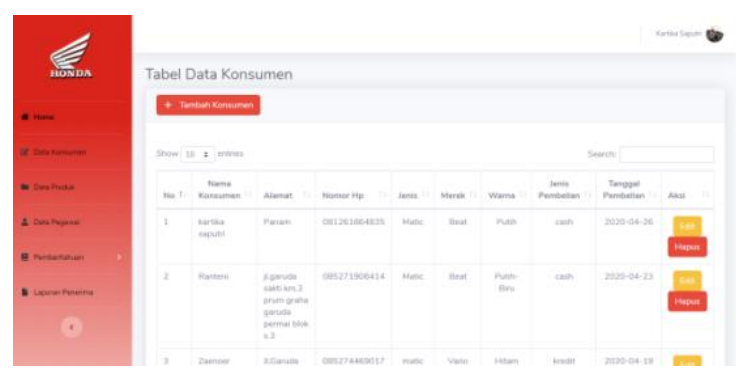

Gambar 10. Halaman Data Konsumen

\section{Data Penerima STNK}

Halaman data penerima STNK berfungsi untuk menampilkan data konsumen penerima STNK, bukan hanya menampilkan data saja. Namun halaman ini di gunakan untuk mengirim sms kepada konsumen ketika data konsumen ter update. Halaman ini juga berlaku untuk Buku Service dan Plat Nomor kendaraan. Berikut tampilan data pada gambar 10, 11 dan 12 sebagai berikut :

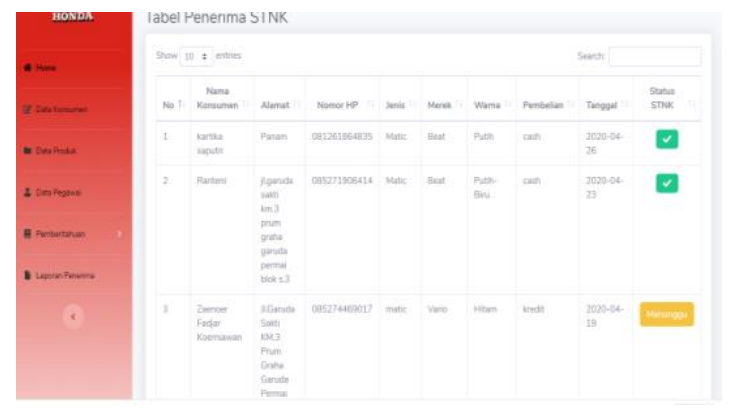

Gambar 11. Halaman Data Penerima STNK

\section{Data Penerima Buku Service}

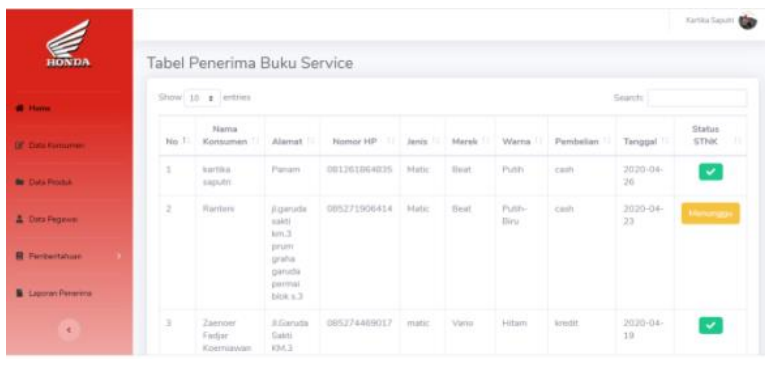

Gambar 12. Halaman Data Penerima Buku Service

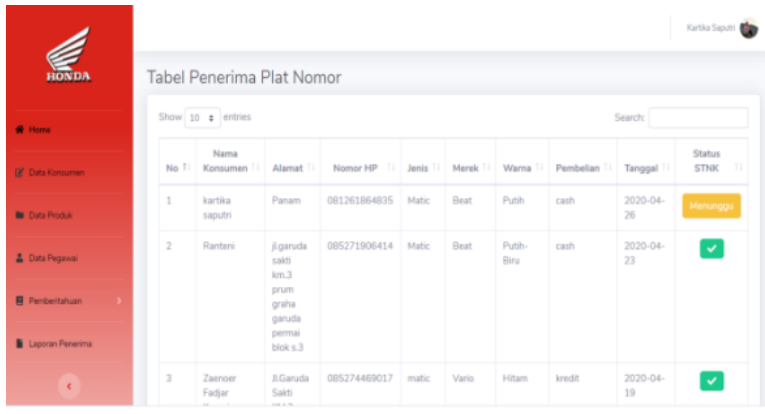

Gambar 13. Halaman Data Penerima Buku Service

6. Halaman Smsgateway.me Halaman smsgateway.me berisikan sebuah kode-kode atau pesan yang digunakan untuk melihat apakah pesan terkitim atau tidak. Dapat dilihat seperti gambar di bawah ini.

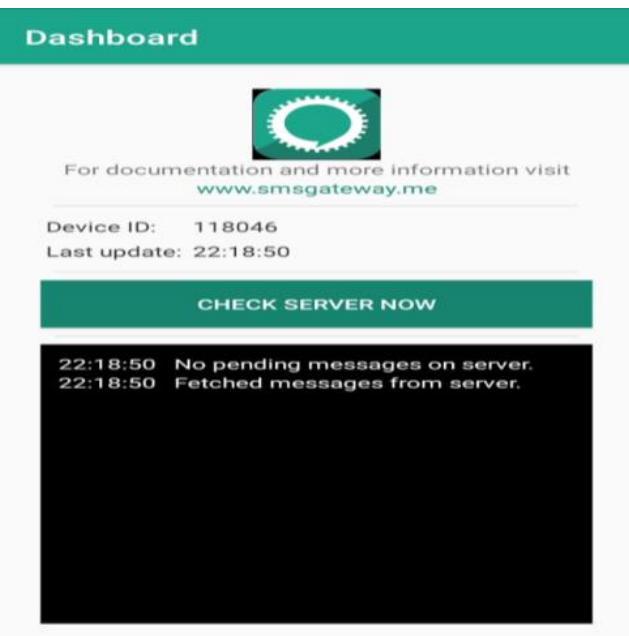

Gambar 14. Halaman Smsgateway.me 


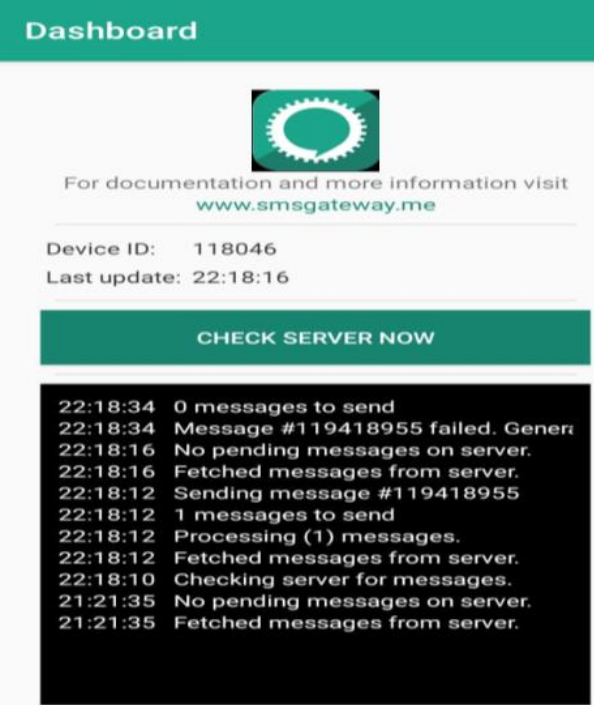

Gambar 15. Halaman Smsgateway.me Terkirim

\section{SIMPULAN}

Kesimpulan dari penelitian ini Teknologi informasi menggunakan SMS Gateway dapat memberikan informasi kepada konsumen secara realtime untuk pengambilan administrasi kendaraan konsumen sehingga konsumen tidak perlu harus bolak balik pergi ke perusahaan untuk menanyakan kesiapan administrasi kendaraan mereka. Dengan teknologi ini pihak perusahaan yaitu Sales Counter dapat lebih mudah memberikan informasi kepada konsumen lebih mudah dan pengolahan data konsumen menggunakan aplikasi yang dihasilkan dari bahasa pemograman.

Saran pada penelitian ini yaitu sistem yang dibangun dapat dikembangkan denga menggunakan android dimana masyarakat sekarang rata - rata sudah memiliki perangkat smart phone yang nantinya aplikasi tersebut bisa didapatkan oleh konsumen di playstore dengan cara mengunduh. Untuk mengingatkan konsumen melakukan pengambilan adaministrasi ditambahkan notifikasi sms.

\section{TERIMA KASIH}

Ucapan Terimakasih penulis ucapkan kepada pimpinan PT. RIAU ARGO
PERKASA yang telah memberikan kesempatan dan mendukung pelaksanaan penelitian ini. Ucapan terimakasih juga bagi pihak karyawan di PT. RIAU ARGO PERKASA yang telah membantu untuk mendapatkan data dan informasi untuk mendukung penelitian ini.

\section{DAFTAR PUSTAKA}

Enjelita, E., \& Oktarina, D. (2019). Rancang Bangun Sistem Informasi Pemesanan Antrian Service Mobil Berbasis Android. Jurnal Mahasiswa Aplikasi Teknologi Komputer Dan Informasi, 1(1), 58-64.

Fandhilah, Pratmanto, D., \& Fatakhudin, A. (2017). Rancang Bangun Sistem Informasi Pemesanan Paket Pernikahan dan Preweding Berbasis Web. Software Engineering, 3(2), 6876.

https://ejournal.bsi.ac.id/ejurnal/index .php/ijse/article/view/2837/1845

Himmah, T. N., \& Azisi, D. S. F. (2019). Pengaruh Perkembangan Teknologi Informasi Terhadap Layanan Perpustakaan IAIN Tulungagung. BiBLIOTIKA, 3(2), 123-130. http://journal2.um.ac.id/index.php/bib liotika

Khaerunnisa, N., \& Nofiyati. (2020). Sistem Informasi Pelayanan Administrasi Kependudukan Berbasis Web syudi Kasus Desa Sidakangen Purbalingga. Jurnal Teknik Informatika, 1(1), 25-32.

Maimunah, Singgih, S., \& Supriyadi, A. (2017). Rancang Bangun Sistem SMS Gateway Sebagai Fasilitas Permohonan Cuti Karyawan. Cerita, 3(1), 36-48.

Nurmalasari, N., Anna, A., \& Arissusandi, R. (2019). Rancang Bangun Sistem Informasi Akuntansi Laporan Laba Rugi Berbasis Web Pada PT. United Tractors Pontianak. Jurnal Sains Dan Manajemen, 7(2), 6-14. 
Ramdhani Nugraha, A., \& Lestrian, D. (2019). Sistem Informasi Geografis Data Kependudukan di Kelurahan Panglayungan Kecamatan Cipedes Kota Tasikmalaya. Jurnal Manajemen Dan Teknik Informatika, 03(01), 81-90.

Simangunsong, A. (2018). Sistem Informasi Pengarsipan Dokumen Berbasis Web. Jurnal Mantik Penusa, 2(1), 11-19. http://ejurnal.pelitanusantara.ac.id/index.php /mantik/article/view/317 